\section{Grafting Technique to Eliminate Rootstock Suckering of Grafted Tomatoes}

\author{
Michael G. Bausher \\ USDA-ARS U.S. Horticultural Research Laboratory, 2001 South Rock Road, \\ Fort Pierce, FL 34982
}

Additional index words. meristems, axillary buds

\begin{abstract}
Vegetative grafting has been proposed as a technique for managing diseases in tomatoes under open-field conditions. Over 2 successive years, we investigated the use of grafting under open-field fresh tomato production and found a serious limitation with current grafting techniques, which resulted in recurring rootstock shoot regrowth ("suckering") from the rootstock cotyledons when left intact. Left unchecked, the regrowth of tomato rootstocks can envelop the experimental scions, which can impact the growth of field-grown tomatoes. In the Fall of 2007, the cultivars Multifort, Aloha, and TX-301 with 'FL-47' scions were grafted by a commercial propagator. These grafted plants were planted in a field experiment and after a time period, the number of rootstock suckers was counted and removed. This process was repeated over five time periods. In 2008, we grafted all of the plants below the rootstock cotyledons. During five different time periods spanning $57 \mathrm{~d}$, bud regrowth from the rootstock occurred in all studied rootstocks in 2007. The difference in the 2 years was dramatic. In the first year, the number of plants with rootstock regrowth was as high as $84.6 \%$ in some of the plots for 'Multifort', 30.7\% for 'Aloha', and 15.4\% for 'TX-301'. In the second year, with a different grafting technique, no regrowth from the rootstocks was observed. Even when the rootstock regrowth was removed in 2007 , the rootstock sprout growth would reappear from the rootstock. The statistical interaction of the percentage of plants with rootstock regrowth for all recorded dates in 2007 was significant for 'Multifort' (Tukey-Fischer $\boldsymbol{P} \leq \mathbf{0 . 0 5}$ ) but not 'Aloha' or 'TX-301'. Although the study also contained fumigation treatments, no interaction of soil treatments on root sprouting was observed. Since adopting this method, rootstock regrowth has not been observed in subsequent field experiments for the past 3 years.
\end{abstract}

The production and consumption of tomatoes in the United States and worldwide ranks it as a major vegetable crop. The use of methyl bromide fumigation for pest control is being phased out under the Montreal Protocol (EPA, 2010). There is also a need to find an alternative pest management program in both sustainable and organic vegetable production. Vegetative grafting is one of these methods and is currently used extensively in a number of countries using methods that produce plants grown in protected environments (Kubota et al., 2008). In the United States, fresh tomato is predominantly grown in the open field using drip or seep irrigation and raised beds covered with plastic mulch. In conventional systems, the soil is fumigated to control weeds and pests. The conditions that exist in the field are quite different from those found in protected agriculture where the plants are covered to give some protection from low-temperature

Received for publication 19 Oct. 2010. Accepted for publication 16 Jan. 2011.

I thank Wang for statistical consultation and the funding agencies USDA-ARS and USDA-NIFA 2007-51106-03794. I also thank Andrew Bantel and Johanna Welsh for their technical assistance during this work and Dongyan.

e-mail michael.bausher@ars.usda.gov. of grafted tomato plants to outgrow the scion. The objective of this article is to describe the issue and outline protocols and procedures to substantially reduce rootstock suckering.

\section{Materials and Methods}

The open-field experiments were conducted at the U.S. Horticultural Research Laboratory (USHRL), Fort Pierce, FL (lat. $27^{\circ} 26^{\prime} 09.39^{\prime \prime} \mathrm{N}$; long. 80²5'53.38" W). Soil type at USHRS is Oldsmar sand (Sandy siliceous, hyperthermic: Alfic Arenic Alaquads). A split plot experiment with four replications was used to evaluate rootstock/scion combinations in fumigated and herbicideonly-treated soil. Experimental plots consisted of a single raised bed covered with metalized polyethylene film with betweenrow spacing of $0.92 \mathrm{~m}$ and in-row spacing of $0.56 \mathrm{~m}$. Four main plot soil treatments were applied under metalized film (Canslit, Montreal, Quebec, Canada): 1) MB (224 kg.ha ${ }^{-1}$, 67:33 MB:chloropicrin); 2) iodomethane (112 kg.ha ${ }^{-1}, 50: 50$ iodomethane:chloropicrin), Midas ${ }^{\circledR}$ (Arysta LifeScience Corp., Tokyo, Japan); 3) dimethyl disulfide (467 $\left.\mathrm{L} \cdot / \mathrm{ha}^{-1}\right)$, 79:21 DMDS:chloropicrin, Paladin ${ }^{\top \mathrm{M}}+$ chloro- $^{-}$ picrin, (United Phosphorous, King of Prussia, PA); 4) a herbicide-only control (0.67 kg.ha ${ }^{-1}$, Dual Magnum ${ }^{\mathrm{TM}}$; Syngenta Crop Protection US, Wilmington, DE; $17.51 \mathrm{~g} \cdot \mathrm{ha}^{-1}$ Matrix ${ }^{\circledR}$; DuPont, Wilmington, DE ; and $26.89 \mathrm{~g} \cdot \mathrm{ha}^{-1}$ Sandea ${ }^{\circledR}$; Gowen Co., Yuma, AR). Subplot treatments in the primary tomato (Solanum esculentum) crop consisted of three rootstocks reported to be resistant to root-knot nematodes (Meloidogyne incognia, M. arenia, M. javanica): 'TX301' (Syngenta Seeds, Minnetonka, $\mathrm{MN})$, 'Multifort' (De Ruiter Seeds, Lakewood, CO), and 'Aloha' (American Takii, Salinas, $\mathrm{CA}$ ), and the non-grafted scion, 'Florida-47' (Seminis Seed, St. Louis, MO) on its own rootstock. Main plots were $30.48 \mathrm{~m}$ long and were split into 7.62-m subplots for each tomato rootstock.

Plant preparation. In Sept. 2007, the plants were grafted and planted by a commercial propagator. In Sept. 2008, the plants were grafted at the USHRL. Scions were seeded in a 242 Speedling ${ }^{\top \mathrm{M}}$ tray, $6.72 \times 3.44 \times 0.63 \mathrm{~cm}$ (Speeding Corp., Sun City, FL) using Fafard 4P (Fafard, Agawam, MA) germination mix with scion planted $3 \mathrm{~d}$ later and grown under greenhouse conditions $\left(29 / 25^{\circ} \mathrm{C}\right.$ day/night). At $23 \mathrm{~d}$, the tomato (two to three true leaf stage) grafting was accomplished using an adaptation of a splice graft held in place by a $1.5-\mathrm{mm}$ silicon grafting clip (BATO, The Netherlands) (Oda, 1995). Studies were 14 plants per plot for each rootstock/scion combination, replicated four times, in four complete blocks designated by fumigation treatment.

Rootstock regrowth. Plants were visually inspected on approximately a weekly basis for the presence of rootstock regrowth (calculated as the percentage of plants with rootstock sprouts). After recording the presence of the rootstock sprouts, they were removed before the next observation. Rootstock regrowth was recorded as adventitious 
growth below the graft union. Results were analyzed using SAS Version 9.1.2 (SAS Institute, Cary, NC) software using the GLIMMIX procedure with Tukey separation at the $P \leq 0.05$ level.

\section{Results and Discussion}

Rootstock regrowth typical of the 2007 trial is shown in Figure 1. The meristems regrowth was quite vigorous on all the rootstocks surveyed and in each case, regrowth came from the area of the rootstocks cotyledon. In the 2007 study, there was rootstock adventitious bud growth (ABG) observed regardless of the rootstock used. The $\mathrm{ABG}$ on 'Multifort' was the most pronounced with mean values ranging from $57 \%$ on the first observation date to $34.1 \%$ on the last date observed [57 d after field transplanting (DAT)] (Fig. 2). These were the highest observed for these respective time periods and were significantly different from other rootstocks. 'Aloha' and 'TX-301' had ABG of $3.4 \%$ and $2.5 \%$, respectively, at 16 DAT. At 57 DAT, the numbers for 'Aloha' and 'TX-301' increased dramatically to $31.1 \%$ for 'Aloha' and 34.2\% for 'TX-301' (Fig. 2).

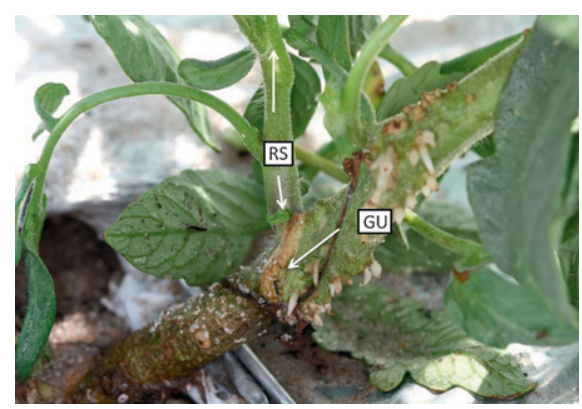

Fig. 1. 'Multifort' rootstock sprout with rootstock bud emerging (RS) below the text box with 'FL-47' scion. Arrow denotes the graft union (GU).
Removing the rootstock's sprouts in the 2007 planting did not deter rootstock regrowth with sprouts still occurring out to over 8 weeks. One explanation for this regrowth is the ability of tomatoes to produce multiple meristems at the cotyledon (Pozueta-Romero et al., 2001; Went, 1944). This explains rootstock shoot regrowth even after root

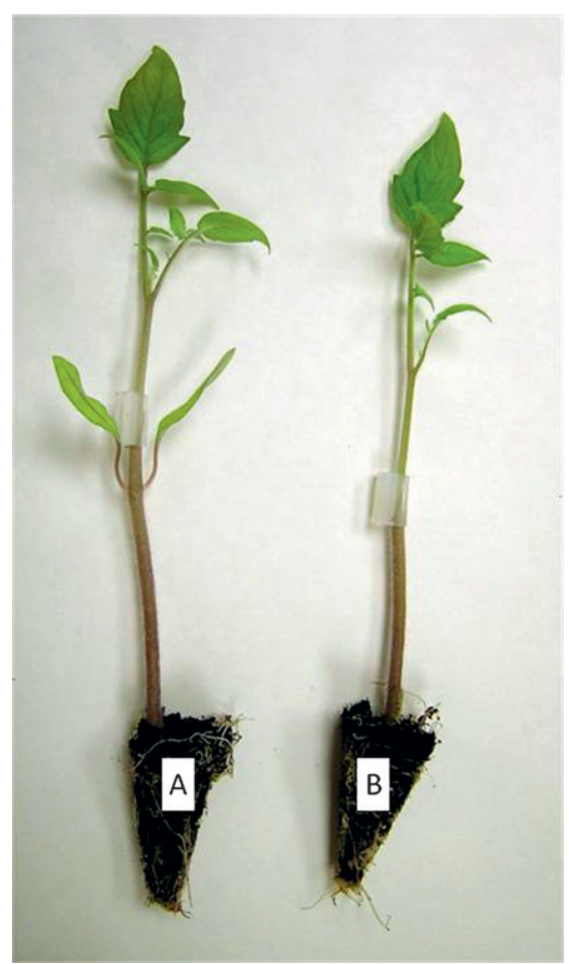

Fig. 3. Image of incorrect (A) and correct (B) method of grafting tomatoes for open field planting. Method A graft above the cotyledons; Method B graft below rootstock cotyledons. The percent sprouts is calculated from the number of plants with rootstock adventitious bud growth $(\mathrm{ABG}) /$ total number of plants assayed.

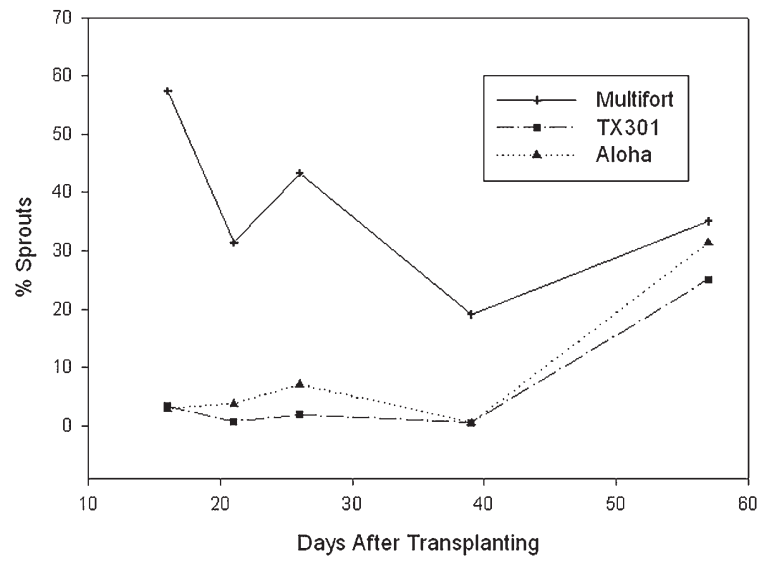

Fig. 2. Illustration of the progression of regrowth of the rootstock from adventurous buds, 'FL-47' scion, in the Fall of 2007-2008. Differences in statistical significance of mean values are valid only at the same time point (Tukey $P .05 \leq 0.0001$ ) and are designated by different letters. sprouts were pruned by tearing the sprout from the stem (which is a commercial practice); however, in subsequent dates, more root sprouts occurred after each removal. Interestingly, between the first removal dates at 16 DAT and 26 DAT, the number of sprouts from the 'Aloha' was $3.4 \%$ and at $57 \mathrm{DAT}$, the number of sprouts increased to $31.4 \%$. In each case of $A B G$, the shoot emerged from the vestigial cotyledon axillary bud (Fig. 1) for each of rootstock types. The presence of $\mathrm{ABG}$ does not correlate with the presence or absence of fumigant treatment and no significance was found between any of the fumigation methods (data not shown). When left unchecked, this rootstock regrowth can easily outgrow the scion and cause abandonment of open-field plots in Florida and other states (Bob Poklemba, Jeremy Taylor, and Josh Freeman, personal communication). Although the axial bud shoots are routinely pruned as a method to improve fruit size, this is an expense that should only be incurred once or twice in a 2-week period after planting (Olson, 2010; Pozueta-Romeroet al., 2001; Went, 1944). Two other factors may influence the regrowth of rootstock meristem: the presence of a determinate scion and the high light intensity of open-field production. In 2008 using the technique of grafting below the cotyledon, as shown in Figure 3, we reduced the $\mathrm{ABG}$ to $0 \%$ for all the rootstocks presented. This style of graft requires lengthened hypocotyls. A method using end-of-day far-red light can aid in the elongation of tomato hypocotyls (Chia and Kubota, 2010).

\section{Conclusion}

Elimination of the cotyledon axillary meristems eliminated the regrowth of the rootstock. Since adopting below the cotyledon grafting, the problem of rootstock regrowth has not recurred.

\section{Literature Cited}

Chia, P. and C. Kubota. 2010. End-of-day far-red light quality and dose requirements for tomato rootstock hypocotyl elongation. HortScience 45:1501-1506.

EPA. 2010. The phaseout of methyl bromide. 30 Sept. 2010. <http://www.epa.gov/ozone/mbr/>.

Hutchinson, C.M. E.H. Simone, G.J. Hochmuth, W.M. Stall, S.M. Olson, S.E. Webb, T.G. Taylor, and S.A. Smith. 2007. Tomato production in Florida. 2007-2008 ed. Univ of Fla, Gainesville, FL.

Kubota, C., M.A. McClure, N. Koklais-Burelle, M.G. Bausher, and E. Rosskopf. 2008. Vegetable grafting: History, use, and current technology status in North America. HortScience 43:1664-1669.

Louws, F. 2006. Grafting for disease resistance in heirloom tomatoes. North Carolina Cooperative Extension Service.

Oda, M. 1995. New grafting methods for fruit bearing vegetables in Japan. Jpn. Agr. Res. Q. 29:187-194.

Oda, M. 1999. Grafting of vegetables to improve greenhouse production. 30 Sept. 2010. <http://www. agnet.org/library/eb/480/> 
Olson, S. 2010. Pruning method effects on yield, fruit size and percentage of marketable fruit of 'Sunny' and 'Solar' set tomatoes. Florida State Hort Soc. 102:324-326.

Pozueta-Romero, J., G. Houln, L. Canas, R. Schantz, and J. Chamarro. 2001. Enhanced regeneration of tomato and pepper seedling explants for Agrobacterium-mediated transformation. Plant Cell Tissue Organ Cult. 67:173180.

Rosskopf, E.N., D.O. Chellemi, N. KokalisBurelle, and G.T. Church. 2005. Alternatives to methyl bromide: A Florida perspective. 29 Oct. 2010. <http://www.apsnet.org/ online/feature/methylbromide/ $>$.

Went, F. 1944. Morphological observation on the tomato plant. Bull. Torrey Bot. Club 71:7792. 